\title{
Sputum viscosity: correlation with chemical and clinical features in chronic bronchitis
}

\author{
MARIA TERESA LOPEZ-VIDRIERO, JANET CHARMAN, \\ E. KEAL, D. J. DE SILVA ${ }^{1}$, and LYNNE REID
}

Department of Experimental Pathology, Cardiothoracic Institute, Brompton Hospital, London S.W.3

Lopez-Vidriero, M. T., Charman, J., Keal, E., de Silva, D. J., and Reid, L. (1973). Thorax, 28, 401-408. Sputum viscosity: correlation with chemical and clinical features in chronic bronchitis. A series of out-patient chronic bronchitics with severe airways obstruction was studied monthly over a five-month period from December 1970 to May 1971; volume, pourability, viscosity, and chemical constituents of sputum, the patients' $\mathrm{FEV}_{1.0} / \mathrm{VC}_{0}$, and viral antibodies were measured.

Mucoid sputum showed a highly significant correlation between pourability grade and viscosity.

The mean coefficient of variation for each feature studied was between 13 and $17 \%$ for pulmonary function tests and between 25 and $44 \%$ for sputum estimations.

Significant inverse correlations were found between sputum volume and viscosity, dry weight yield, neuraminic acid (NANA), and fucose, and a positive correlation with $\mathrm{FEV}_{1 \cdot 0} / \mathrm{VC} \%$.

Linear correlations showed that mucoid sputum dry weight yield correlated with NANA and fucose concentrations, viscosity with NANA, dry weight, and fucose, in ascending order of significance. Mucopurulent sputum viscosity correlated to a much less degree with NANA.

Second order partial correlation coefficients showed that for mucoid sputum viscosity was affected equally by dry weight and fucose but not by NANA: for mucopurulent sputum fucose was twice as influential as dry weight while NANA showed an inverse correlation with viscosity (probably because of degradation of NANA).

Taking all patients and samples together, a significant inverse correlation was found between sputum viscosity and absolute values of $\mathrm{FEV}_{1.0}$ and $\mathrm{FEV}_{1.0} / \mathrm{VC} \%$, and between $\mathrm{FEV}_{1.0} / \mathrm{VC}_{\mathrm{O}} \%$ and NANA.

Seven patients showed considerable monthly changes in sputum viscosity, NANA, and fucose concentrations, which were high in December and in February or March, coinciding with peaks in atmospheric smoke and sulphur dioxide. No patient showed any evidence of viral infection.

Previous studies on sputum variation have been confined to inter-aliquot variation (Blanshard, 1955 ; Palmer, 1957 ; Goldfarb and Buchberg, 1964 ; Charman and Reid, 1972) and intra-disease variation (Charman and Reid, 1972). The present study is the first time that seasonal or monthly patient variations have been studied in detail. Keal and Reid (1972) have reported a similar winter study on chronic bronchitis but the chemical estimations were less detailed and direct viscosity measurements were not carried out. In a study of

1Wandsworth Chest Clinic, Municipal Buildings, Fairfield Street, London S.W.18 chronic bronchitics, Elmes, Dutton, and Fletcher (1959) measured the sputum volume on two occasions in the winter months and obtained a similar result on each occasion. In the same study an inverse correlation was found between sputum volume in the first hour after waking and the patient's maximum breathing capacity. Keal and Reid (1972) found no correlation between sputum 'pourability' and the degree of airways obstruction in patients with respiratory disease. In five patients with cystic fibrosis, Feather and Russell (1970) reported a significant negative correlation between pulmonary function and viscosity. 
The importance of neuraminic acid (NANA) in determining viscosity was first indicated by Odin (1958), who found that the viscid gel of pseudomyxomatous ovarian cysts had $10 \%$ of NANA in the dried material whereas the less viscous fluid from pseudomucinous cysts contained only $2 \%$. Gibbons (1959) and Gibbons and Glover (1959) found changes in the viscosity of bovine cervical mucus that correlated with the NANA content. A high correlation between sputum viscosity and NANA was reported by Munies, Grubb, and Caliari (1968). Further work by Keal (1971a) on mucoid sputum in chronic bronchitics has confirmed the importance of NANA in determining sputum 'pourability'.

The viscosity of mucoid sputum has also been shown to be related to the yield of dry macromolecular material (Keal and Reid, 1972). A NANA/fucose ratio had previously been used by Keal (1971b) to determine the contribution of bronchial mucous gland secretion and serous exudate in sputum since fucose is present in mucus but not in exudate whereas NANA is in both.

The purpose of the present study was to correlate viscosity measured with the Ferranti-Shirley viscometer with detailed chemical studies and respiratory function tests, the sputum being collected over a short time and tested immediately. The fact that the patients in this study were attending an outpatient clinic meant a longer time lag between sputum production and its testing than in our previous studies.

\section{MATERIAL AND METHODS}

Seventeen patients, all men between 63 and 75 years of age and suffering from chronic bronchitis as defined by the Medical Research Council (1965), were included in the study from December 1970 to May 1971. Four patients also had localized and one generalized emphysema but none had evidence of asthma or bronchiectasis. One left the trial after two visits but all the others attended the Wandsworth Chest Clinic about once in every four weeks.

On the day of each visit the sputum produced in the first hour after waking was coughed into a sterile glass universal container and taken by the patient to the clinic where a blood sample was taken to test for viral antibodies and lung function tests were carried out.

SPUTUM Each fresh sputum specimen was examined macroscopically and classified as mucoid ( $M-$ no evidence of pus), purulent ( $\mathrm{P}$ - uniformly purulent, whether green or yellow) or mucopurulent (MPmixed). This last category was further subdivided into three grades according to whether pus or mucus was predominant (MMP, MP or MPP).

The volume of each specimen was measured to the nearest millilitre. A pourability grading was given to each according to the ease of flow from an inverted container:

Grade 1-adheres closely to the container

Grade 2-moves slowly with gravity

Grade 3-slides in one mass

Grade 4-pours easily but may have viscid particles Intermediate grades, e.g., $1 / 2,2 / 3$, etc., were alsorecognized (Keal and Reid, 1972).

A fresh sample from each specimen without pre $=$ treatment was taken for viscosity measurements on $\omega$ Ferranti-Shirley viscometer (Palmer, Ballantyne Diament, and Hamilton, 1970 ; Charman and Reid $x$ 1972).

The remainder of the sputum was stored at $-20^{\circ} \mathrm{C} \triangle$ for chemical studies that included estimation of : +

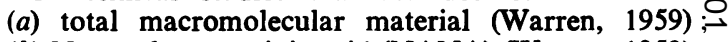
(b) N-acetyl neuraminic acid (NANA) (Warren, 1959) and (c) methyl-pentose-fucose (Gibbons, 1955).

CLINICAL Reports on the radiographs were prepared $€$ by Dr. G. Simon, special attention being paid to any evidence of emphysema or heart failure (Simon, 1970) $\vec{\bullet}$

Values of FEV $V_{1.0}$ and VC were obtained using as 2-litre water spirometer. The heights and weights of the patients were taken in order to estimate their predictedo values, using Kory's nomogram (Kory, Callahan Boren, and Syner, 1961).

Complement fixation tests were carried out for the following: influenza virus $A, B$, and $C$, adenovirus, respiratory syncytial virus, $Q$ fever, psittacosis, and Mycoplasma pneumoniae.

POLLUTION Mean monthly measurements of atmo spheric pollution, that is, concentration (in micro grammes per cubic metre) of smoke and sulphur. dioxide, for the Borough were obtained from the Health Department, Wandsworth Council.

\section{RESULTS}

Statistical analyses of the results of the five macro scopic groups (M, MMP, MP, MPP, and P) indi cated that for the chemical and physical featureso measured the MMP and MPP values were suffi ciently consistent with the MP group to permie them to be included with them, as was done sub $\frac{\bar{\pi}}{\pi}$ sequently.

POURABILITY AND VISCOSITY For each macroscopiq type the correlation coefficient was calculated fof the association between the pourability grade anc the apparent viscosity of the sputum at a shear rate of $90 \mathrm{~s}^{-1}$. For mucoid sputum a highly significan and inverse correlation was found between the pourability grade and the viscosity, but when pus? was present the correlation coefficient was not significantly different from zero (Table I). The mean viscosity of the specimens containing pu\& was higher than for mucoid but the pourabilit. grade did not decrease correspondingly. All the 
T A B L E I

CORRELATION COEFFICIENTS FOR POURABILITY GRADE AND VISCOSITY FOR EACH MACROSCOPIC SPUTUM TYPE

\begin{tabular}{l|c|c}
\hline $\begin{array}{l}\text { Macroscopic } \\
\text { Sputum Type }\end{array}$ & No. of Specimens & $\begin{array}{c}\text { Correlation } \\
\text { Coefficient }\end{array}$ \\
\hline Mucoid & 38 & $+0 \cdot 5647^{1}$ \\
Mucopurulent & 33 & $-0 \cdot 2634$ \\
Purulent & 6 & -0.0375 \\
\hline
\end{tabular}

${ }^{1} \mathbf{P}<0 \cdot 001$.

purulent specimens had viscosity values similar to those of the most viscous mucoid specimens.

MACROSCOPIC SPUTUM TYPES There was no significant difference between mucoid and mucopurulent specimens for the mean values of any of the chemical or functional features listed in Table II. There were not enough purulent specimens to make a valid comparison with these, although the purulent tended to have a higher viscosity and dry weight yield and a lower NANA fucose ratio than either of the other two groups.
IND:VIDUAL PATIENT VARIATION The average coefficient of variation $\left(\frac{\text { standard deviation }}{\text { mean }} \times 100\right)$ for individual patients ranged from $13.1 \%$ to $17 \%$ for the $\mathrm{FEV}_{1.0} / \mathrm{VC} \%$ and from $25 \%$ to $44.8 \%$ for the sputum estimations. The measurements of lung function of a given patient were less variable by half than the physical and chemical properties of his sputum.

VARIATION WITHIN MACROSCOPIC SPUTUM TYPES For any one patient, taking the mucoid and mucopurulent specimens separately, the coefficient of variation was similar, that is, there was no difference in variation in any one patient when the sputum changed from one macroscopic type to another.

vOLUME A significant and inverse correlation was demonstrated between sputum volume and viscosity (poise), dry weight yield $(\mathrm{mg} / \mathrm{ml})$, NANA

\section{T A B L E I I}

MEAN VALUES FOR SPUTUM VOLUME, VISCOSITY AND CHEMICAL CONSTITUENTS AND PATIENT'S RESPIRATORY FUNCTION TESTS RELATED TO THE THREE MACROSCOPIC SPUTUM TYPES

\begin{tabular}{|c|c|c|c|c|c|c|c|c|c|c|c|c|}
\hline $\begin{array}{c}\text { Macroscopic } \\
\text { Sputum } \\
\text { Type }\end{array}$ & $\begin{array}{c}\text { No. of } \\
\text { Specimens }\end{array}$ & $\underset{(\mathrm{ml})}{\text { Volume }}$ & $\begin{array}{l}\text { Viscosity } \\
\text { at } 90 \mathrm{~s}_{-1} \\
\text { (poise) }\end{array}$ & $\underset{(\mathrm{mg} / \mathrm{ml})}{\mathrm{D} . \mathrm{W}}$ & 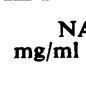 & D.w. & $\underset{\mathrm{mg} / \mathrm{m} \mathbf{l}}{\mathbf{F}}$ & D. W. & $\begin{array}{c}\text { NANA/F } \\
\text { Ratio }\end{array}$ & $\mathrm{FEV}_{\mathbf{1 \cdot 9}}$ & $\underset{(\%)}{\left.\mathrm{FEV}_{1.0} / \mathrm{VC}\right)}$ & VC \\
\hline $\begin{array}{l}\text { Mucoid } \\
\text { Mucopurulent } \\
\text { Purulent } \quad \text {. }\end{array}$ & $\begin{array}{r}38 \\
33 \\
6\end{array}$ & $\begin{array}{c}5 \cdot 48 \\
(0 \cdot 47)_{1} \\
7 \cdot 46 \\
(0 \cdot 97) \\
5 \cdot 33 \\
(1 \cdot 76)\end{array}$ & $\begin{array}{c}4 \cdot 20 \\
(0 \cdot 43) \\
4 \cdot 59 \\
(0 \cdot 64) \\
7 \cdot 10 \\
(1 \cdot 30)\end{array}$ & $\begin{array}{l}18 \cdot 81 \\
(1 \cdot 37) \\
23 \cdot 10 \\
(1 \cdot 68) \\
30 \cdot 15 \\
(3 \cdot 35)\end{array}$ & $\begin{array}{c}0.83 \\
(0.10) \\
0.98 \\
(0.10) \\
0.95 \\
(0.23)\end{array}$ & $\begin{array}{c}4 \cdot 66 \\
(0 \cdot 26) \\
4 \cdot 21 \\
(0 \cdot 25) \\
3 \cdot 25 \\
(0 \cdot 51)\end{array}$ & \begin{tabular}{|c|}
1.01 \\
$(0.11)$ \\
1.21 \\
$(0.13)$ \\
1.75 \\
$(0.25)$
\end{tabular} & $\begin{array}{c}5 \cdot 79 \\
(0 \cdot 33) \\
5 \cdot 37 \\
(0 \cdot 32) \\
6 \cdot 39 \\
(1 \cdot 33)\end{array}$ & $\begin{array}{c}0.83 \\
(0.05) \\
0.85 \\
(0.05) \\
0.54 \\
(0.10)\end{array}$ & \begin{tabular}{|c|}
$903 \cdot 13$ \\
$(80 \cdot 77)$ \\
$975 \cdot 00$ \\
$(78 \cdot 58)$ \\
$825 \cdot 00$ \\
$(68 \cdot 02)$
\end{tabular} & $\begin{array}{l}54 \cdot 14 \\
(2 \cdot 27) \\
53 \cdot 40 \\
(2 \cdot 25) \\
51 \cdot 05 \\
(4 \cdot 95)\end{array}$ & $\begin{array}{r}1,643 \cdot 75 \\
(109 \cdot 00) \\
1,817 \cdot 86 \\
(112 \cdot 70) \\
1,633 \cdot 33 \\
(84 \cdot 34)\end{array}$ \\
\hline
\end{tabular}

${ }_{1}$ S.E. of mean; NANA $=\mathrm{N}$-acetyl neuraminic acid; D.W. $=$ dry weight; $F=$ fucose.

T A B L E I I I

CORRELATION COEFFICIENTS BETWEEN VOLUME AND VISCOSITY, CHEMISTRY, AND RESPIRATORY FUNCTION

\begin{tabular}{c|c|c|c|c|c|c|c|c|c|}
\hline $\begin{array}{c}\text { Viscosity at } \\
90 \mathrm{~s}_{-1}(\text { poise })\end{array}$ & $\begin{array}{c}\text { Dry weight } \\
(\mathrm{mg} / \mathrm{ml})\end{array}$ & $\begin{array}{c}\text { NANA } \\
(\% \mathrm{DW})\end{array}$ & $\begin{array}{c}\text { NANA } \\
(\mathrm{mg} / \mathrm{ml})\end{array}$ & $\begin{array}{c}\text { Fucose } \\
(\% \mathrm{DW})\end{array}$ & $\begin{array}{c}\text { Fucose } \\
(\mathrm{mg} / \mathrm{ml})\end{array}$ & FEV $_{1 \cdot 0}$ & VC & FEV ${ }^{\circ} \cdot \mathrm{VC} \%$ \\
\hline$-0.3425^{1}$ & $-0.3324^{1}$ & -0.1577 & $-0.2509^{2}$ & -0.0354 & $-0.2417^{2}$ & +0.0546 & -0.1326 & $+0.3096^{1}$ \\
\hline
\end{tabular}

${ }^{1} \mathrm{P}<0.01 ;{ }^{2} \mathrm{P}<0.05$.

T A B LE I V

LINEAR CORRELATION COEFFICIENTS BETWEEN VISCOSITY AND CHEMICAL MEASUREMENTS FOR MACROSCOPIC SPUTUM TYPES

\begin{tabular}{|c|c|c|c|c|c|c|c|c|c|}
\hline \multirow{3}{*}{\multicolumn{2}{|c|}{$\begin{array}{c}\text { Macroscopic } \\
\text { Type of } \\
\text { of Sputum }\end{array}$}} & & \multicolumn{6}{|c|}{ Correlation Coefficient between } & \multirow{3}{*}{$\begin{array}{c}\overline{\text { Fucose }(\mathrm{mg} / \mathrm{ml})} \\
\text { and } \\
\text { NANA } \\
\text { (mg/ml) }\end{array}$} \\
\hline & & & \multicolumn{4}{|c|}{$\begin{array}{l}\text { Viscosity (poise) } \\
\text { and }\end{array}$} & \multicolumn{2}{|c|}{$\begin{array}{c}\text { Dry Weight }(\mathrm{mg} / \mathrm{ml}) \\
\text { and }\end{array}$} & \\
\hline & & & $\underset{(\mathrm{mg} / \mathrm{ml})}{\mathrm{DW}}$ & $\begin{array}{l}\text { NANA } \\
(\mathrm{mg} / \mathrm{ml})\end{array}$ & $\begin{array}{c}\text { Fucose } \\
(\mathrm{mg} / \mathrm{ml})\end{array}$ & NANA/fucose & $\begin{array}{l}\text { NANA } \\
(\mathbf{m g} / \mathbf{m l})\end{array}$ & $\begin{array}{c}\text { Fucose } \\
(\mathrm{mg} / \mathrm{ml})\end{array}$ & \\
\hline $\begin{array}{l}\text { Mucoid . } \\
\text { Mucopurulent } \\
\text { Purulent .. }\end{array}$ & $\begin{array}{l}\cdots \\
\cdots\end{array}$ & $\begin{array}{l}\cdots \\
\cdots\end{array}$ & $\begin{array}{l}+0.68^{1} \\
+0.62^{1} \\
-0.75\end{array}$ & $\begin{array}{l}+0.66^{1} \\
+0.38^{2} \\
-0.88^{2}\end{array}$ & $\begin{array}{l}+0.73^{1} \\
+0.79^{1} \\
-0.60\end{array}$ & $\begin{array}{r}-0.07 \\
-0.21 \\
+0.06\end{array}$ & $\begin{array}{l}+0.67^{1} \\
+0.75^{1} \\
+0.69\end{array}$ & $\begin{array}{l}+0.70^{1} \\
+0.71^{1} \\
-0.06\end{array}$ & $\begin{array}{l}+0.84^{1} \\
+0.65^{1} \\
+0.65\end{array}$ \\
\hline
\end{tabular}


( $\mathrm{mg} / \mathrm{ml})$, and fucose $(\mathrm{mg} / \mathrm{ml})$, and a significant and positive one between volume and $\mathrm{FEV}_{1.0} / \mathrm{VC} \%$ (Table III). Although the correlation coefficients are significantly different from zero it is evident from the Table that the correlations are not strong. The trend is that the more sputum produced by the patient within the hour of collection, the less viscid it is, the lower its dry weight yield, neuraminic acid, and fucose content and the higher the patient's $\mathrm{FEV}_{1 \cdot 0} / \mathrm{VC} \%$.

VISCOSITY AND CHEMICAL MEASUREMENTS Linear correlation coefficients were established between the measurements of viscosity and the chemical properties of the sputum for each macroscopic type (Table IV). The purulent group is included in the Table but the number of specimens is too few to be useful for statistical comparison with the other groups.

The linear correlations showed that in mucoid sputum the dry weight yield was highly correlated with the concentration of both NANA and fucose, particularly fucose. NANA and fucose concentrations were highly correlated with each other. Viscosity showed a similar significant correlation with NANA, dry weight, and fucose, in ascending order.

In mucopurulent sputum dry weight yield was highly correlated with NANA and fucose, most significantly with NANA: again NANA and fucose were highly correlated but not as highly as in mucoid sputum. Viscosity showed a significant correlation with dry weight and fucose, especially fucose, and a low degree of correlation with NANA.

When the dependent variable, in this case viscosity, is correlated with several other variables, e.g., dry weight yield $(\mathrm{mg} / \mathrm{ml})$, NANA $(\mathrm{mg} / \mathrm{ml})$, and fucose $(\mathrm{mg} / \mathrm{ml})$, which are not independent since they are correlated with each other, then the simple correlation between viscosity and any one of the variables is affected by this intercorrelation. Second order partial correlation coefficients, i.e., partial correlations between viscosity and one variable holding the other two constant, were therefore established (Table V).

In mucoid sputum, taking viscosity as the dependent variable, values for the second order partial correlation coefficients with dry weight and fucose were similar, that with NANA negligible. In mucopurulent sputum the partial correlation coefficients between viscosity and fucose were extremely high, about twice as high as with dry weight: NANA was decreasing as viscosity rose. There were not enough purulent specimens for a similar analysis to be useful since the partial correlation coefficients
T A B L E V

PARTIAL CORRELATION COEFFICIENTS BETWEEN VISCOSITY AND CHEMICAL CONSTITUENTS

\begin{tabular}{c|ccc}
\hline & $\begin{array}{c}\text { Dry Weight } \\
(\mathrm{mg} / \mathrm{ml})\end{array}$ & $\begin{array}{c}\text { NANA } \\
(\mathrm{mg} / \mathrm{ml})\end{array}$ & $\begin{array}{c}\text { Fucose } \\
(\mathrm{mg} / \mathrm{ml})\end{array}$ \\
\hline $\begin{array}{c}\text { Holding } \\
\text { Constant }\end{array}$ & $\begin{array}{c}\text { NANA and } \\
\text { Fucose }\end{array}$ & $\begin{array}{c}\text { Dry Weight } \\
\text { and Fucose }\end{array}$ & $\begin{array}{c}\text { Dry Weight } \\
\text { and NANA }\end{array}$ \\
\hline $\begin{array}{l}\text { Mucoid } \\
\text { Mucopurulent }\end{array}$ & $\begin{array}{c}+0.3294^{3} \\
+0.3501^{3}\end{array}$ & $\begin{array}{c}+0.0503 \\
-0.4178^{2}\end{array}$ & $\begin{array}{l}+0.3409^{3} \\
+0.7019^{1}\end{array}$ \\
\hline
\end{tabular}

${ }^{1} \mathbf{P}<0.001$

${ }^{2} \mathbf{P}<0.02$
${ }^{3} \mathbf{P}<0.05$

have a large standard error and none reached significance.

The high correlation between fucose and NANA in mucoid sputum means that there is a high degree of predictability of viscosity from the concentration of either of these substances. The regression line with the $95 \%$ confidence limits for the relationship between NANA and fucose is plotted in Figure 1. From this the NANA equivalent to fucose can be calculated and then the NANA from serum estimated by subtracting the calculated from the observed value. For example, the dotted line shown in the Figure indicates that if the fucose value is $2.0 \mathrm{mg} / \mathrm{ml}$ then the NANA equivalent would have a $95 \%$ confidence interval of $1.28-1.96$ with a mean of $1.62 \mathrm{mg} / \mathrm{ml}$. If the observed NANA value was $2.4 \mathrm{mg} / \mathrm{ml}$, the serum derived NANA would be between 0.44 and 1.22 with a mean of $0.78 \mathrm{mg} / \mathrm{ml}$.

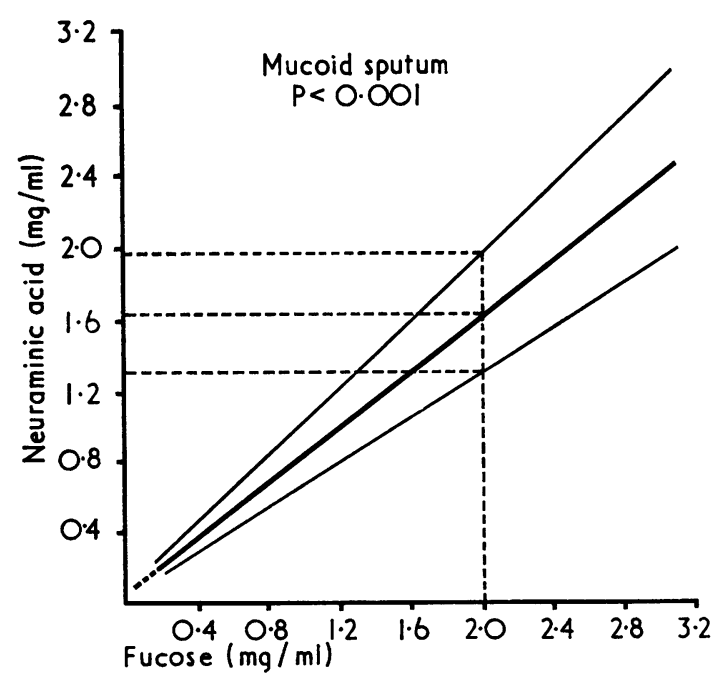

FIG. 1. Regression line with $95 \%$ confidence limits for the relationship between fucose and neuraminic acid concentrations. 
T A B LE V I

CORRELATION COEFFICIENTS BETWEEN ABSOLUTE LEVELS OF FEV ESTIMATIONS $_{1 \cdot 0}$ AND FEV $_{1 \cdot 0 / V C} \%$ AND VISCOSITY AND CHEMICAL

\begin{tabular}{|c|c|c|c|c|c|c|c|}
\hline & $\begin{array}{c}\text { Viscosity } \\
\text { (poise) }\end{array}$ & $\underset{(\mathrm{mg} / \mathrm{ml})}{\text { Dry Weight }}$ & $\underset{(\mathrm{mg} / \mathrm{ml})}{\text { NANA }}$ & $\begin{array}{l}\text { NANA } \\
(\% \text { DW })\end{array}$ & $\begin{array}{c}\text { Fucose } \\
(\mathrm{mg} / \mathrm{ml})\end{array}$ & $\begin{array}{l}\text { Fucose } \\
\text { (\% DW) }\end{array}$ & NANA/Fucose \\
\hline $\begin{array}{l}\mathrm{FEV}_{1 \cdot 0} / \mathrm{FE} \% \\
\mathrm{FEV}_{1 \cdot 0} / \mathrm{VC} \%\end{array}$ & $\begin{array}{l}-0.4583^{1} \\
-0.2982^{2}\end{array}$ & $\begin{array}{l}+0.0508 \\
-0.0713\end{array}$ & $\begin{array}{l}+0.0788 \\
-0.2569^{2}\end{array}$ & $\begin{array}{l}+0.2055 \\
-0.2523^{2}\end{array}$ & $\begin{array}{l}-0.1153 \\
-0.1951\end{array}$ & $\begin{array}{l}-0 \cdot 1108 \\
-0.0479\end{array}$ & $\begin{array}{l}-0.0739 \\
-0.0993\end{array}$ \\
\hline
\end{tabular}

${ }^{1} \mathrm{P}<0.001 ;{ }^{2} \mathrm{P}<0.02 ;{ }^{2} \mathrm{P}<0.05$.

AIRWAYS OBSTRUCTION AND SPUTUM VISCOSITY Taking all patients and samples together, there was a highly significant inverse correlation between sputum viscosity and $\mathrm{FEV}_{1.0}$ measured on the day of sputum production $(\mathrm{P}<0.001)$. When patients were studied individually, eight showed this inverse correlation and six showed a direct correlation, but in no case was the correlation coefficient significantly different from zero. The readings for $\mathrm{FEV}_{1.0}$ for any one patient showed only a small scatter. For the group no significant correlation emerged between sputum viscosity and vital capacity.

A significant inverse correlation was found for the group between sputum viscosity and $\mathrm{FEV}_{1.0} /$ $\mathrm{VC} \%(\mathrm{P}<0.02)$. When patients were studied individually nine showed this inverse correlation of which three were significantly different from zero: of the five that showed a positive correlation, only two were significantly different from zero.

AIRWAYS OBSTRUCTION AND THE CHEMICAL CONSTITUENTS OF SPUTUM Correlation coefficients were estimated between either $\mathrm{FEV}_{1.0}$ and $\mathrm{FEV}_{1.0} /$ $\mathrm{VC} \%$ and the chemical constitutents of the sputum produced on the same day (Table VI). For FEV 1.0 no significant correlations emerged. $\mathrm{FEV}_{1.0} / \mathrm{VC}^{2}$ showed a significant and inverse correlation only with NANA, expressed either as a percentage of dry weight or as $\mathrm{mg} / \mathrm{ml}$ of sputum.

ATMOSPhERIC POLLution Figure 2 shows the mean figures for the concentration of smoke and sulphur dioxide in microgrammes per cubic metre for the five months studied. Smoke was at its highest in December while sulphur dioxide showed a peak in February. The values for sputum viscosity and NANA and fucose content (each as $\mathrm{mg} / \mathrm{ml}$ ) were plotted for individual patients and compared with the pollution patterns. Nine cases showed hardly any change throughout: in the other seven the trend was for high sputum values in both December when smoke was at its highest, and then in either February or March, sulphur dioxide showing a peak in February. In three cases this latter increase continued on through April and May.

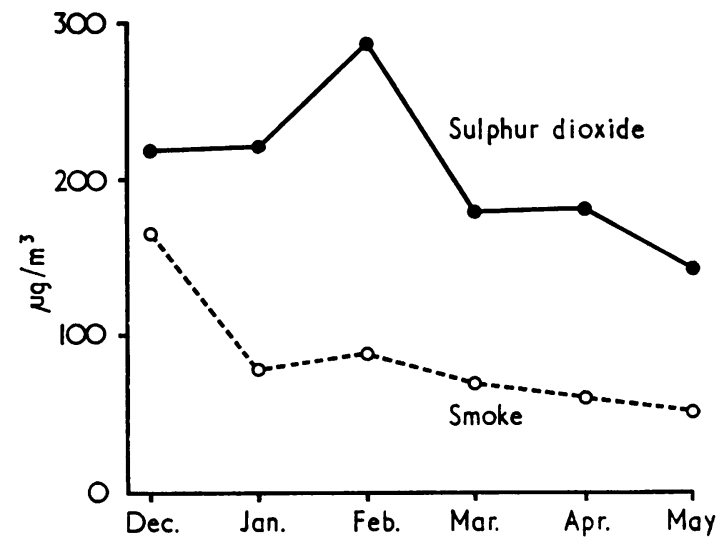

FIG. 2. Average concentration of atmospheric sulphur dioxide and smoke in the Borough of Wandsworth from December 1970 to May 1971.

VIROLOGICAL STUDIES On no occasion did any patient have a positive serological result, i.e., a titre of more than 1 in 160. Several patients had titres of 1 in 80 for influenza $A$ virus but all these had received an influenza virus vaccination at the beginning of the winter.

RADIOLOGY In 11 of the patients the radiographs showed no evidence of emphysema; in four, localized areas of emphysema were seen and in only one widespread emphysema. One patient with no evidence of emphysema showed signs of pulmonary hypertension. The sputum of these last two patients, however, was in no way different from that of the others in the group, nor were their respiratory function tests.

\section{DISCUSSION}

GROUP STUDIED The patients were all chronic bronchitics within the MRC definition (Medical Research Council, 1965) but all severe in that there was airways obstruction with considerable disability. Keal and Reid (1972) found hardly any difference between groups of 'early' and severe 
chronic bronchitics as regards the sputum dry weight yield and NANA $(\mathrm{mg} / \mathrm{ml}$ and $\%$ of dry weight), although a higher NANA/fucose ratio was found in the 'early' group (Keal and Reid, 1973). When the present series was compared with that of Keal and Reid (1973) the figures were similar, although in the present series a wider range of NANA was found. The NANA/ fucose ratio resembled that of Keal's 'early' chronic bronchitics more closely than his severe cases.

INDIVIDUAL PATIENT VARIATION The mean coefficient of variation for viscosity within a specimen of sputum from patients with chronic bronchitis has previously been found to be $17 \%$ (Charman and Reid, 1972), that between patients with chronic bronchitis $57 \%$. It is therefore not surprising to find in the present study that the mean coefficient of variation for one patient, studied on various occasions, was found to be $41 \%$. The coefficients of variation for the chemical constituents of the sputum were all of the same order of magnitude; that for the variation in lung function was only half that for the chemical findings.

Although there were only five purulent specimens, they appeared more viscous than the mucoid and mucopurulent specimens as previously reported (Sturgess, Palfrey, and Reid, 1970, 1971 ; Dulfano, Adler, and Philippoff, 1971 ; Charman and Reid, 1972) and their dry weight content was high.

The concentration of NANA $(\mathrm{mg} / \mathrm{ml})$ was similar for all macroscopic sputum types but as a percentage of the dry weight it decreased with increased purulence. In contrast, the fucose increased with purulence, expressed both as a concentration $(\mathrm{mg} / \mathrm{ml})$ and as a percentage of dry weight, suggesting that in chronic bronchitis there is more mucus secretion when the sputum is purulent.

In a series of patients with cystic fibrosis or bronchiectasis, who intermittently produced purulent sputum, Keal and Reid (1973) found lower levels of fucose than are reported here in bronchitic sputum, presumably because mucous gland hypertrophy was not present in the former groups (Lamb, 1969).

The NANA/fucose ratio was similar in mucoid and mucopurulent specimens but was lower in purulent specimens. This may have been because these samples were kept longer before refrigeration than those in our earlier studies and the activity of bacterial enzymes such as neuramini- dase or aldolase may have liberated and degraded NANA (Woodcraft, Roberts, and Reid, 1973).

The mean viscosity values for mucoid and mucopurulent specimens were similar and support earlier findings (Charman and Reid, 1972). Also there was little difference in the mean values for dry weight yield, NANA or fucose concentrations between the two groups.

VISCOSITY AND CHEMICAL CORRELATION The linear correlation coefficients between viscosity and the chemical constituents of the sputum were similar for both mucoid and mucopurulent sputum. For purulent sputum no useful conclusions can be reached since there are too few specimens.

The strong correlation between fucose and viscosity for both mucoid and mucopurulent sputum has not been previously demonstrated, although Keal and Reid (1972) suggested that dry weight was more significant than NANA. The latter constituent was previously thought to be the most important (Munies et al., 1968 ; Keal, 1971a, b). Furthermore, Gibbons (1959) and Gibbons and Glover (1959) emphasized its importance in cervical mucus where considerable change in viscosity was associated chemically only with a change in NANA.

While fucose and NANA are both constituents of the acid glycoprotein of epithelial mucus, serum contains virtually no fucose. On the other hand, serum has a high dry weight yield and low viscosity with a NANA content per millilitre similar to that of sputum. It is unlikely that the physicochemical properties of fucose, a pentose sugar, can explain the correlations we have demonstrated. Perhaps fucose is better regarded as a marker or measure of the acid glycoprotein constituent of sputum, whereas NANA represents, in addition, the tissue fluid component, in mucoid sputum a transudate. When inflammatory exudate is also present it will further influence the NANA content.

PARTIAL CORRELATION COEFFICIENTS From second order partial correlation coefficients it appears that for mucoid sputum the total dry weight and fucose concentration per unit volume are both equally important as regards viscosity. Each of these is probably closely related to the acid glycoprotein, since in mucoid sputum any transudate present probably has a relatively low dry weight yield. The NANA content has little effect on viscosity which suggests that the serum contribution of this substance is of little significance.

In mucopurulent sputum fucose is twice as 
important a determinant of viscosity as the dry weight. This probably means that here fucose is the satisfactory measure of the acid glycoprotein, since even dry weight will be influenced by pus. Furthermore, the importance of fucose suggests that even when pus is present mucus is more important to the level of viscosity.

Keal (1971b) has emphasized the importance of the NANA-fucose ratio in freshly collected purulent sputum as a measure of the exudate and mucus components. Further studies are being done on more samples of purulent sputum freshly collected from chronic bronchitics than were included here.

The close correlation between fucose and viscosity suggests that it is the mucus that influences viscosity. It may be possible from the regression line relating NANA to fucose concentration to estimate from the sputum fucose level the equivalent weight of NANA which would be regarded as the mucus contribution. From this the tissue fluid NANA could be estimated.

The patients in this study are all chronic bronchitics ; similar correlations have not yet been established for other diseases.

volume The significant inverse correlation between sputum viscosity and volume suggests that the increased volume represents dilution of the mucus secretion. This is supported by the fact that the dry weight yield, NANA, and fucose concentrations (each in $\mathrm{mg} / \mathrm{ml}$ ) also fall, although when expressed as a percentage of dry weight there is no correlation. Keal $(1970 a$; 1971a) reported a similar finding of increased NANA with decreased volume of sputum during steroid treatment of asthmatics with bronchorrhoea.

The inverse correlation between volume and viscosity, and the positive correlation with respiratory function, could mean that a less viscous specimen is easier to cough up, as suggested by Dulfano et al. (1971). This is the reasoning behind the use of mucolytic agents. It is unlikely that a larger sputum volume is directly related to better function: this effect probably arises from the lower viscosity values found when more sputum is produced, or it may be that a greater volume of a low viscosity sputum is characteristic of a stage of the disease at which organic airways obstruction is less severe.

POURABILITY AND VISCOSITY The pourability grade and viscosity of mucoid sputum correlated very closely, as previously shown (Keal, 1970b ; Keal and Reid, 1971), but not in specimens containing pus which were more viscous but poured readily from the container. This may be because a purulent specimen is often surrounded by a thin layer of watery fluid which alters its surface properties, allowing a viscous specimen to slide easily and thus to be given a higher pourability grading. This emphasizes that features other than viscosity may be important in determining biological behaviour. The fact that purulent sputum pours easily may reflect the easier clearance often reported by the patient.

RESPIRATORY FUNCTION It might be expected that a viscous fluid blocks a tube more effectively or persistently than a less viscous one. Clarke, Jones, and Oliver (1970), in an investigation of the effect on resistance to air flow of the nature of fluid lining a tube, showed that over a range of viscosity, relevant to sputum, a more viscous fluid increased resistance. In our study a correlation was found between the viscosity of the sputum and the severity of airways obstruction. In individual patients this pattern did not emerge as strongly but in all the variation in $\mathrm{FEV}_{\mathbf{1 \cdot 0}}$ was small.

Where predicted values were available the correlation was less close than with absolute values, perhaps because in patients with seriously impaired function the obstruction mainly arises from structural change, and viscosity will probably have little effect. More detailed studies are planned on patients with either chronic bronchitis or other diseases, with a higher degree of reversibility of airways obstruction.

ATMOSPHERIC POLLUTION In some patients certain features varied with the degree of pollution. This was less marked than Keal (1970a) and Keal and Reid (1972) found for Newcastle from 1962 to 1965. There may also have been a correlation with temperature or humidity but these were not measured.

VIROLOGY The year reported in this study was surprisingly free from viral infections. The current winter will probably be more rewarding, since viral infections are already (October 1972) occurring, and it is planned to repeat the study.

We are grateful to Dr. K. M. Citron, consultant physician, Wandsworth Chest Clinic, for his co-operation in this study; to Dr. G. Simon for reading the chest radiographs : to Mr. J. Smith, Divisional Public Health Inspector, Wandsworth, for providing us with the meteorological details; to Miss Sue Yelland and Dr. R. W. Riddell, Department of Microbiology. Brompton Hospital, for carrying out the virological tests, and to Professor B. Benjamin, Civil Service College, for help with the statistical analysis. 


\section{REFERENCES}

Blanshard, G. (1955). The viscometry of sputum. Archives of the Middlesex Hospital, 5, 222.

Charman, J., and Reid, L. (1972). Sputum viscosity in chronic bronchitis, bronchiectasis, asthma and cystic fibrosis. Biorheology, 9, 185.

Clarke, S. W., Jones, J. G., and Oliver, D. R. (1970). Resistance to two-phase gas-liquid flow in airways. Journal of Applied Physiology, 29, 464.

Dulfano, M. J., Adler, K., and Philippoff, W. (1971). Sputum viscoelasticity in chronic bronchitis. American Review of Respiratory Diseases, 104, 88.

Elmes, P. C., Dutton, A. A. C., and Fletcher, C. M. (1959). Sputum examination and the investigation of "chronic bronchitis'. Lancet, 1, 1241.

Feather, E. A., and Russell, G. (1970). Sputum viscosity and pulmonary function in cystic fibrosis. Archives of Diseases in Childhood, 45, 807.

Gibbons, M. N. (1955). The determination of methylpentoses. Analyst, 80, 268.

Gibbons, R. A. (1959). Chemical properties of two mucoids from bovine cervical mucin. Biochemical Journal, 73, 209.

- - and Glover, F. A. (1959). The physicochemical properties of two mucoids from bovine cervical mucin. Biochemical Journal, 73, 217.

Goldfarb, H., and Buchberg, A. S. (1964). The rheology of human respiratory tract mucus and its relationship to ciliary activity. Clinical Research, 12, 291.

Keal, E. (1970a). Modifications des propriétés physicochimiques de l'expectoration dans divers états pathologiques et leur traitement. Poumon et le Coeur, 26, 25.

- (1970b). Methodes d'étude des modifications de la sécrétion bronchique et de sa viscosité. Poumon et le Coeur, 26, 51.

- (1971a). Biochemistry and rheology of sputum in asthma. Postgraduate Medical Journal, 47, 171.

—_ (1971b). Étude anatomique de la bronchite des gros troncs. In Pathologie et Nosologie de la Bronchite Chronique, Colloque de Lyon, 22/23 Septembre 1970, p. 15. Edited by l'Association Médicale et Scientifique de Lutte contre la Bronchite Chronique.

_ and Reid, L. (1971). Der Bronchialschleim-seine Bildung, Zusammensetzung und physikalischen Eigenschaften. Internist, 12, 416.
_- (1972). The neuraminic acid content of sputum in chronic bronchitis. Thorax, 27, 643 .

_- (1973). Neuraminic acid, fucose and sulphate levels in sputum: as evidence of its source in hyper- $\overline{\bar{\omega}}$ secretory and inflammatory states (chronic bronchitis. bronchiectasis and cystic fibrosis). (In preparation.)

Kory, R. C., Callahan, R., Boren, H. G., and Syner, J. C. ़ְ (1961). Clinical spirometry in normal men. American Journal of Medicine, 30, 243.

Lamb, D. (1969). Acidic glycoproteins of the mucous glands $\vec{\overrightarrow{ }}$ of the bronchus in cystic fibrosis. In Hypersécrétion $\vec{\omega}$ Bronchique, Colloque International de Pathologie Thoracique, Lille, 27/29 Septembre 1968, p. 143.

Medical Research Council (1965). Definition and classi-i fication of chronic bronchitis. Committee on the Aetiology of Chronic Bronchitis. Lancet, 1, 775.

Munies, R., Grubb, T. C., and Caliari, R. E. (1968). Relationship between sputum viscosity and total sialic acid content. Journal of Pharmaceutical Science, 57, 824.

Odin, L. (1958). Mucopolysaccharides of epithelial mucus. Ciba Foundation Symposium on the Chemistry and $\subseteq$ Biology of Mucopolysaccharides, edited by G. E. W. Wolstenholme and M. O'Connor, p. 234. Churchill. $\vec{\oplus}$ London.

Palmer, K. N. V. (1957). The effect of an aerosol detergent ${ }^{\omega}$ in chronic bronchitis. Lancet, 1, 611 .

- Ballantyne, D., Diament, M. L., and Hamilton, W. F. D. (1970). The rheology of bronchitic sputum. British Journal of Diseases of the Chest, 64, 185.

Simon, G. (1970). Radiology and chronic airways obstruction $\frac{\text { Dे }}{2}$ in Modern Trends in Diagnostic Radiology, 4th series, edited by J. W. McLaren, pp. 21-38. Butterworths, $\overline{\widehat{O}}$ London.

Sturgess, J. M., Palfrey, A. J., and Reid, L. (1970). The viscosity of bronchial secretion. Clinical Science, 38, 145.0 Rheologica Acta, 10, 36.

Warren, L. (1959). The thiobarbituric acid assay of sialic acids. Journal of Biological Chemistry, 234, 1971.

Woodcraft, S., Roberts, G. P., and Reid, L. (1973). The presence of neuraminidase ( $\mathrm{N}$-acetyl-neuraminate glycohydrolase EC 32118 ) in sputum and its effect on윽 the isolation of glycoproteins from sputum. ( Inß preparation.) 